\title{
Change in Self-Evaluation of Hearing Status According to Age: A Population-Based Study
}

\author{
Seok-Youl Choi ${ }^{1}$, Jee Won Moon ${ }^{1}$, June Choi ${ }^{2}$, Jae-Jun Song ${ }^{1}$, Gi Jung Im $^{3}$, and Sung-Won Chae ${ }^{1}$ (D) \\ ${ }^{I}$ Department of Otorhinolaryngology-Head and Neck Surgery, Korea University Guro Hospital, Korea University College of Medicine, \\ Seoul; and ${ }^{2}$ Department of Otorhinolaryngology-Head and Neck Surgery, Korea University Ansan Hospital, \\ Korea University College of Medicine, Seoul; and ${ }^{3}$ Department of Otorhinolaryngology-Head and Neck Surgery, \\ Korea University Anam Hospital, Korea University College of Medicine, Seoul, Korea
}

\section{연령별 난청 자가 인식과 청력역치 관계}

최석열 ${ }^{1} \cdot$ 문지원 ${ }^{1}$ 최 준 $^{2} \cdot$ 송재준 $^{1} \cdot$ 임기정 ${ }^{3} \cdot$ 채성원 $^{1}$

${ }^{1}$ 고려대학교 의과대학 구로병원 이비인후-두경부외과학교실, ${ }^{2}$ 고려대학교 의과대학 안산병원 이비인후-두경부외과학교실,

3 고려대학교 의과대학 안암병원 이비인후-두경부외과학교실

\author{
Received June 19,2021 \\ Revised September 6, 2021 \\ Accepted September 27, 2021 \\ Address for correspondence \\ Sung-Won Chae, MD, PhD \\ Department of Otorhinolaryngology- \\ Head and Neck Surgery, \\ Korea University Guro Hospital, \\ Korea University \\ College of Medicine, \\ 148 Gurodong-ro, Guro-gu, \\ Seoul 08308, Korea \\ Tel +82-2-2626-3186 \\ Fax $+82-2-868-0475$ \\ E-mail koreachae@gmail.com
}

Background and Objectives Self-reported hearing levels determined by self-report questionnaires are not always correlated with the audiometric hearing level. It is necessary to ascertain the subjectively perceived normal hearing threshold to determine the need for hearing aids at the appropriate time. The objective is to identify the level of correlation between the self-reported hearing level and the audiometric hearing level and ascertain the subjectively perceived normal hearing threshold for each age group.

Subjects and Method This cross-sectional study, using the data from the Korea National Health and Nutrition Examination Survey V, looked at participants with hearing loss who were aged $\geq 40$ years. Pure tone audiometry was conducted bilaterally. Self-reported hearing level was ascertained via survey enquiring about hearing loss. The level of correlation between self-reported hearing level and audiometric hearing level, age-specific patterns of hearing self-evaluation and subjectively perceived normal hearing values at which participants complained of hearing loss were main outcomes.

Results Mean audiometric thresholds (MATs) increased with the age and degree of self-reported hearing level. The accuracy of self-reported hearing level compared to the audiometric threshold decreased with age both in the better-ear and worse-ear groups. Younger participants tended to overestimate their hearing impairment, while older participants tended to underestimate it. Subjectively perceived normal hearing thresholds increased with age and they were very close to the MATs for each age group.

Conclusion Results can be useful for devising different age-group specific pure tone audiometry-based diagnostic criteria for self-reported hearing loss, which can be used to determine the need for hearing aid in a timely manner.

Korean J Otorhinolaryngol-Head Neck Surg 2021;64(12):861-7

Keywords Audiometric hearing loss; Cut-off values; Percent correct classification; Presbycusis; Self-reported hearing loss.

This is an Open Access article distributed under the terms of the Creative Commons Attribution Non-Commercial License (https://creativecommons.org/licenses/by-nc/4.0) which permits unrestricted non-commercial use, distribution, and reproduction in any medium, provided the original work is properly cited. 


\section{Introduction}

Self-reported hearing level ascertained by questionnaires is not always correlated with audiometric hearing level; this discrepancy has been widely reported by several studies. ${ }^{1-5)}$ The discrepancy rate was $18.2 \%$ and $28.2 \%$ in Korean individuals aged $\geq 20$ years and American individuals aged $\geq 50$ years, respectively. ${ }^{3,4)}$ Most of the previous studies have focused on reporting factors associated this discrepancy and there has been few studies about how this discrepancy rate changes according to age. For example, a study utilizing data from the Korean National Health and Nutrition Examination Survey only focused on the socioeconomic and emotional factors predicting the discrepancy between the audiometric threshold and self-reported hearing level. ${ }^{1)}$ However, another study utilizing data from the National Health and Nutrition Examination Survey of U.S. population showed that the discrepancy rate increased, the rate of overestimation decreased, and the rate of underestimation increased with ages. ${ }^{3)}$ Younger individuals tended to overestimate their hearing loss, while older individuals tended to underestimate it.

Self-reported hearing level is a crucial evaluation tool because the need for hearing rehabilitation such as hearing aids or relevant training is occasionally driven by self-reported hearing loss instead of an audiometric hearing loss. Individuals who overestimate their hearing inconvenience may purchase hearing aids unnecessarily. On the contrary, individuals who underestimate their hearing inconvenience may not be able to get help from hearing aids because they do not visit the hearing care clinics. Therefore, it is necessary to determine the degree of correlation between self-reported hearing level and the audiometric thresholds.

In the present study, we aimed to identify the level of correlation between self-reported hearing level and audiometric hearing level according to age using data from the Korean National Health and Nutrition Exhibition Survey V (20102012) and inferred the patterns of hearing self-assessment from the relative ratio of underestimation and overestimation according to age. Moreover, we hypothesized that the cut-off values of the pure tone audiometry threshold, which were devoid of overestimation and underestimation, would be equivalent to the subjectively perceived normal hearing threshold, with an aim to ascertain the perceived normal hearing levels for each age group.

\section{Subjects and Methods}

\section{Study population}

This study used data from the Korean National Health and Nutrition Examination Survey V (KNHANES V), a crosssectional survey of the South Korean population (51.6 million) conducted by the Korean Ministry of Health and Welfare. This nationwide survey includes health/nutrition interviews and health examinations. This survey recruits 10000-12000 individuals from approximately 4600 households every year to represent the population using a multi-stage clustered and stratified random sampling method. The acquired data has been kept open to the public by the Korea Center for Disease Control and Prevention (KCDC). The study described here adhered to the tenets of the Declaration of Helsinki, and written informed consent was obtained from all participants. The survey protocol was approved by the Institutional Review Board of the KCDC (IRB No: 2010-02CON-21-C). A survey was conducted on pure tone audiometry and self-reported hearing level in individuals aged $\geq 12$ years. Participants who were treated for otitis media within the past 2 weeks; those who showed abnormal auricular findings; those who underwent external auditory canal and tympanic membrane (TM) examination, which revealed TM perforation, cholesteatoma, exudative otitis media, and chronic otitis media; and those who were $<40$ years old (since they showed normal hearing on pure tone audiometry) were excluded from this study. Hence, a total of 9877 participants were included in this study.

\section{Assessment of audiometric hearing level}

Audiometric hearing level was determined using the average audiometric threshold at four frequencies $(0.5,1,2$, and $4 \mathrm{kHz}$ ). An audiometric threshold over $25 \mathrm{~dB}$ was defined as the audiometric hearing loss, and the presence of hearing loss was recorded. Audiometric evaluation was conducted on both ears, and subsequently divided into the "better-ear" and "worse-ear."

\section{Assessment of self-reported hearing level}

Data on the self-reported hearing level were collected via a questionnaire survey that enquired about any hearing inconvenience in individuals ages $\geq 40$ years in case they were not using any hearing aid. The responses were presented in the multiple-choice format: 1) "No trouble in hearing," 2) "Mild trouble in hearing," 3) "Considerable trouble in hearing," and 4) "Cannot hear at all." Responses of " 2 ," "3," or " 4 " 
corresponded to the presence of self-reported hearing loss. Then, we summarized the presence or absence of self-reported hearing loss based on the results of the survey. Participants in a group of category 4 (cannot hear at all) were counted as part of category 3 (considerable trouble in hearing) for statistical analysis, and they accounted for $0.19 \%$ of the total participants.

\section{Estimation of subjectively perceived normal hearing threshold}

Assuming that the existence of self-reported hearing loss was a confirmatory diagnostic criterion for hearing loss, instead of audiometric threshold, we extracted the receiver operating characteristic (ROC) curve for various values of the audiometric threshold and calculated the area under the curve (AUC) for each age. The cut-off point on the ROC curve at which the sensitivity and specificity were equal was calculated. We hypothesized that participants would continue to perceive their hearing level as normal or complain of hearing impairment at this point. The accuracy of the test was measured using the area under the ROC curve, which was interpreted as fair if its values were $\geq 0.7{ }^{6)}$

\section{Statistical analysis}

Statistical analysis was performed using Statistical Package for the Social Sciences software (version 22.0; IBM Corp., Armonk, NY, USA). By classifying the entire study population into men and women, we recorded the mean age, mean audiometric threshold (MAT), age distribution and self-reported hearing level distribution. The MAT by group depending on the survey response of self-reported hearing level were obtained and age-based audiometric threshold trends were recorded within the same group. The results were expressed as mean (standard deviation).

Furthermore, percent correct classification and misclassification bias were calculated to identify the correlation between the audiometric thresholds and self-reported hearing level. ${ }^{3)}$ Percent correct classification was defined as the total number of correctly classified participants divided by the total number of all participants. If both the audiometric thresholds and self-reported hearing level indicated the absence or presence of hearing loss simultaneously, it was considered correctly classified group. Misclassification bias indicated the percentage of overestimated or underestimated responses among misclassified answers. In detail, participants who selfreported hearing loss even with a normal range of audiometric threshold would overestimate their hearing level, and par- ticipants without self-reported hearing loss with an abnormal range of audiometric threshold would underestimate their hearing level. A $2 \times 2$ table was created to show the presence or absence of hearing loss according to the audiometric threshold and self-reported hearing level, and the correct classification ratio and misclassification bias were calculated in the form of overestimation and underestimation. A subanalysis was performed to determine the level of percent correct classification and misclassification bias depending on sex and age. The chi-square test was used to compare the percent correct classification and misclassification bias with respect to sex and age group.

\section{Results}

A total of 9877 participants comprising 4273 male and 5604 female were included in this study (mean age 57.98 years). The MAT at four frequencies for the better and worse ears were 17.09 and $23.87 \mathrm{~dB}$, respectively. Although the audiometric thresholds for the better and worse ears were higher in men than in women, there was no significant difference in the mean age of men and women. The number of women and men in each age group and self-reported hearing level group did not differ significantly (Table 1).

The MATs increased with age and the degree of self-reported hearing level (Table 2). However, not all subgroups showed concordance between audiometric hearing level and self-reported hearing level. For example, the MATs for the better and worse ears in participants complaining of mild difficulty in hearing in the 40-49 years age group was 12.1 and $21.4 \mathrm{~dB}$ respectively, which were within the normal ranges.

The accuracy of self-reported hearing level compared to the audiometric threshold expressed by the percent correct classification decreased with age in the better-ear and worse-ear groups (Table 3). Moreover, the rate of overestimation decreased, while that of underestimation increased with age, as revealed by the misclassification bias for the better- and worseear groups. For better ears, the percent correct classification for the 40-49 and 70-79 years age groups was 93.4\% and $65.5 \%$, respectively. Participants in the $40-49$ years age group tended to overestimate their hearing impairment, while those in the 70-79 years age group tended to underestimate it $(81.0 \%$ overestimation in the $40-49$ years age group versus $80.5 \%$ underestimation in the 70-79 years age group). The point of inflection was around the age of 60 years. For worse ears, the percent correct classification decreased with age, but partici- 
Table 1. Clinical characteristics of the study population

\begin{tabular}{|c|c|c|c|}
\hline & Total $(n=9877)$ & Male $(n=4273)$ & Female $(n=5604)$ \\
\hline Age $(y r)$ & $57.98 \pm 11.35$ & $58.07 \pm 11.36$ & $57.91 \pm 11.34$ \\
\hline \multicolumn{4}{|l|}{ Hearing threshold (dB) } \\
\hline Better ear & $17.09 \pm 13.61$ & $18.57 \pm 13.81$ & $15.95 \pm 13.34$ \\
\hline Worse ear & $23.87 \pm 18.05$ & $25.67 \pm 18.16$ & $22.50 \pm 17.84$ \\
\hline \multicolumn{4}{|l|}{ Age groups (yr) } \\
\hline $40-49$ & $2722(27.55)$ & $1182(27.66)$ & $1540(27.48)$ \\
\hline $50-59$ & $2817(28.52)$ & $1171(27.40)$ & $1646(29.37)$ \\
\hline $60-69$ & $2388(24.17)$ & $1079(25.25)$ & $1309(23.35)$ \\
\hline $70-79$ & $1950(19.74)$ & $841(19.68)$ & $1109(19.78)$ \\
\hline \multicolumn{4}{|l|}{ Self-reported hearing level } \\
\hline No trouble in hearing & $8172(82.73)$ & $3503(81.97)$ & $4669(83.31)$ \\
\hline Mild trouble in hearing & $1401(14.18)$ & $619(14.48)$ & $782(13.95)$ \\
\hline Considerable trouble in hearing & $304(3.07)$ & $151(3.53)$ & $153(2.73)$ \\
\hline
\end{tabular}

Data are presented as the mean \pm standard deviation or $\mathrm{n}(\%)$

Table 2. Hearing threshold (dB) by age of each self-reported hearing level group

\begin{tabular}{|c|c|c|c|}
\hline $\begin{array}{l}\text { Age } \\
\text { groups }\end{array}$ & $\begin{array}{c}\text { No trouble } \\
\text { hearing }\end{array}$ & $\begin{array}{l}\text { Mild trouble } \\
\text { hearing }\end{array}$ & $\begin{array}{l}\text { Considerable } \\
\text { trouble hearing }\end{array}$ \\
\hline \multicolumn{4}{|c|}{ Better ear (yr) } \\
\hline $40-49$ & $8.3 \pm 6.6$ & $12.1 \pm 9.4$ & $28.1 \pm 30.1$ \\
\hline $50-59$ & $12.3 \pm 8.3$ & $18.5 \pm 12.7$ & $36.2 \pm 20.9$ \\
\hline $60-69$ & $18.4 \pm 11.0$ & $27.5 \pm 12.7$ & $43.0 \pm 20.7$ \\
\hline $70-79$ & $25.0 \pm 12.3$ & $35.0 \pm 13.0$ & $48.0 \pm 17.9$ \\
\hline \multicolumn{4}{|c|}{ Worse ear (yr) } \\
\hline $40-49$ & $13.0 \pm 10.5$ & $21.4 \pm 7.2$ & $45.0 \pm 29.0$ \\
\hline $50-59$ & $18.1 \pm 12.9$ & $27.1 \pm 17.1$ & $63.0 \pm 26.8$ \\
\hline $60-69$ & $24.9 \pm 14.4$ & $38.3 \pm 18.6$ & $60.2 \pm 22.6$ \\
\hline $70-79$ & $32.5 \pm 16.1$ & $45.2 \pm 17.4$ & $62.3 \pm 20.2$ \\
\hline
\end{tabular}

Hearing thresholds are given as mean \pm standard deviation values of audiometric thresholds for $0.5,1,2$, and $4 \mathrm{kHz}$ and reported as $\mathrm{dB}$

pants in all age groups tended to underestimate their hearing impairment.

The subjectively perceived normal hearing threshold for each age group was estimated by extracting the cut-off values of the audiometric threshold from the ROC curve (Table 4). In the better-ear group, the cut-off value showed fair AUC for those over 60 years age, and it was anticipated that the participants in the 60-69 and 70-79 years age groups would complain of hearing loss at 20.5 and $29.5 \mathrm{~dB}$, respectively. In the worse-ear group, the cut-off values were 18.5, 28.5, and 37.5 $\mathrm{dB}$ for participants in the 50-59, 60-69, and 70-79 years age groups respectively, which showed a fair AUC for the age groups over 50 years. The subjectively perceived normal hearing threshold increased with age in the better-ear and worseear groups, but it was higher in the worse-ear group than in the better-ear group.

\section{Discussion}

Currently, the average audiometric threshold at four frequencies $(0.5,1,2$, and $4 \mathrm{kHz})$ in the better ear is the gold standard for the diagnostic assessment of hearing loss by WHO criteria. ${ }^{7)}$ An audiometric threshold over $25 \mathrm{~dB}$ typically leads to the diagnosis of hearing loss. Self-report questionnaires that evaluate the level of hearing loss are also frequently used as simple screening methods. As the self-reported hearing level increased, the audiometric hearing threshold also increased (Table 2). However, self-reported hearing level overestimated the number of people with hearing loss for those between 40 and 59 years old in better-ear groups. In contrary, self-reported hearing level underestimated the number of people with hearing loss for those 70 years or older in worse-ear groups. Therefore, audiometric threshold is not an accurate predictor of self-reported hearing loss.

This discrepancy has been well demonstrated by this study and Kamil, et al.'s ${ }^{3)}$ study. The percent correct classification decreased with age in both studies, and participants tended to underestimate their hearing loss as they became older (Table 3). On the contrary, younger participants tended to overestimate their hearing impairment. Social comparison theory can explain the patterns of self-hearing evaluation by age. ${ }^{5)}$ Older adults tend to underestimate their physical disability because they make downward social comparisons by expecting more severe physical disability for most other people. Moreover, elderly people can perceive hearing impairment as a normal aging process and its gradual process makes them adjusted to it. ${ }^{8)}$ However, younger adults tend to overestimate their physical disability because they make upward social comparisons 
Table 3. Percent correct classification and misclassification bias of audiometric hearing loss compared to self-reported hearing loss

\begin{tabular}{|c|c|c|c|c|c|}
\hline & \multicolumn{5}{|c|}{ Better/worse ear } \\
\hline & \multirow{2}{*}{$\begin{array}{l}\text { Percent correct } \\
\text { classification (\%) }\end{array}$} & \multirow{2}{*}{ p-value } & \multicolumn{2}{|c|}{ Misclassification bias } & \multirow{2}{*}{ p-value } \\
\hline & & & Overestimation (\%) & Underestimation (\%) & \\
\hline Overall & $81.3 / 74.2$ & & $41.7 / 18.8$ & $58.2 / 81.0$ & \\
\hline Sex & & $0.008 / 0.005$ & & & $<0.001 /<0.001$ \\
\hline Male & $80.1 / 72.8$ & & $35.7 / 14.1$ & $64.3 / 85.9$ & \\
\hline Female & $82.2 / 75.3$ & & $46.9 / 22.8$ & $53.1 / 77.2$ & \\
\hline Age groups (yr) & & $<0.001 /<0.001$ & & & $<0.001 /<0.001$ \\
\hline $40-49$ & $93.4 / 90.3$ & & $81.0 / 41.9$ & 19.0/58.1 & \\
\hline $50-59$ & $86.0 / 79.3$ & & $64.9 / 31.3$ & $35.1 / 68.7$ & \\
\hline $60-69$ & $74.8 / 65.1$ & & $39.8 / 15.6$ & $60.2 / 84.4$ & \\
\hline $70-79$ & $65.5 / 55.7$ & & $19.5 / 6.6$ & $80.5 / 93.4$ & \\
\hline
\end{tabular}

Table 4. MATs by age and cut-off value of hearing threshold (dB) for self-reported hearing loss (better/worse ear)

\begin{tabular}{|c|c|c|c|c|c|}
\hline $\begin{array}{l}\text { Age } \\
\text { groups }\end{array}$ & $\begin{array}{l}\text { MAT } \\
(\mathrm{dB})\end{array}$ & $\begin{array}{l}\text { Cut-off } \\
\text { value } \\
\text { (dB) }\end{array}$ & Ss (\%) & $\mathrm{Sp}(\%)$ & $\mathrm{AUC}(95 \% \mathrm{Cl})$ \\
\hline
\end{tabular}

Better ear (yr)

$\begin{array}{rrrrrr}40-49 & 8.6 & 8.5 & 60.8 & 56.9 & 0.63(0.58-0.68) \\ 50-59 & 13.3 & 13.5 & 61.7 & 62.6 & 0.67(0.64-0.70) \\ 60-69 & 21.0 & 20.5 & 67.2 & 67.2 & 0.74(0.72-0.76) \\ 70-79 & 29.6 & 29.5 & 73.3 & 69.0 & 0.77(0.75-0.79)\end{array}$

Worse ear $(\mathrm{yr})$

\begin{tabular}{llllll}
$40-49$ & 13.7 & 13.5 & 65.1 & 63.1 & $0.68(0.64-0.73)$ \\
$50-59$ & 19.5 & 18.5 & 67.0 & 63.8 & $0.71(0.67-0.73)$ \\
$60-69$ & 28.7 & 28.5 & 70.2 & 69.7 & $0.76(0.74-0.79)$ \\
$70-79$ & 38.4 & 37.5 & 73.9 & 71.5 & $0.78(0.76-0.80)$ \\
\hline
\end{tabular}

Hearing thresholds are given as mean values of the audiometric thresholds for $0.5,1,2$, and $4 \mathrm{kHz}$. MAT, mean audiometric threshold; Ss, sensitivity; Sp, specificity; $\mathrm{Cl}$, confidence interval; AUC, area under the curve

with more advanced persons in social activities so that they need the greater demands on their physical ability. Further investigation found that the percent correct classification in better-ear group was higher than that in worse-ear group for all participants and regardless of gender or age (Table 3), and this was thought to be the fact that the participants mainly relied on their better ear when they had a different level of hearing. The point of inflection from overestimation to underestimation of hearing loss in the better ear was around the age of 60 years in this study (Table 3), while the results of other study was around the age of 70 years. ${ }^{3)}$ The point of inflection may vary from society to society because self-assessed normal hearing level typically tends to follow the value considered normal in the society in which participants belong.

Several studies have defined conditions for the prediction of audiometric hearing loss using self-reported hearing level. In a previous study, participants aged $45-65$ years complained of hearing impairment at an audiometric threshold over 25 $\mathrm{dB}$ of four frequencies $(0.5,1,2$, and $4 \mathrm{kHz})$ in the worse ear, with a sensitivity of $59 \%$ and specificity of $90 \%$, ${ }^{9}$ while in another study, self-reported hearing loss has $100 \%$ sensitivity and $70.7 \%$ specificity for hearing thresholds over $40 \mathrm{~dB}$ in a population aged $70-85$ years, including moderate and greater degrees of self-reported hearing loss. ${ }^{10)}$ However, the degree and patterns of self-hearing evaluation substantially differ according to age, and the need for hearing rehabilitation such as hearing aids or relevant training is occasionally driven by self-reported hearing loss instead of an audiometric hearing loss. Therefore, it is necessary to determine the cut-off values of the audiometric hearing threshold that may be perceived as an abnormality in hearing in each age group (Table 4), which were presumed to be the subjectively perceived agebased normal hearing threshold in our study. For comparison, the MATs for the 40-49, 50-59, 60-69, and 70-79 years age groups were also calculated as 8.6, 13.3, 21.0, and 29.6 dB, respectively, for the better-ear and 13.7, 19.5, 28.7, and 38.4 $\mathrm{dB}$, respectively, in the worse-ear group. The cut-off values for each age group were very close to the MATs for the better- and worse-ear groups, which reflected a strong correlation between the cut-off values and the actual MATs for each age group. In other words, individuals would start to complain of hearing impairment when their audiometric thresholds become equal to or greater than the mean hearing threshold of their age group.

In this study, the cut-off values of the audiometric threshold for self-reported hearing loss increased with age, meaning that participants started tolerating their hearing inconvenience 
as they became older. The cut-off values for the worse-ear group were 5 and $8 \mathrm{~dB}$ higher than those of the better-ear group in participants aged $40-59$ and $60-79$ years, respectively. The reason why differences in cut-off values between better- and worse-ear groups increased in older age groups was that selfreported hearing loss might be affected by binaurally in addition to dominant hearing in younger age while determined by dominant hearing in older age. Sensitivity, specificity and AUC increased with age and they were higher in worse-ear groups than better-ear groups because participants would be generally more likely to complain of subjective hearing loss as their audiometric threshold increased. Subjectively perceived normal hearing thresholds were still within $25 \mathrm{~dB}$ till the age of 69 years for the better ear and 59 years for the worse ear. Therefore, simultaneous consideration of the audiometric threshold for the better- and worse-ears is recommended for defining the subjectively perceived normal hearing threshold.

This study has several limitations. First, although participants with abnormal TM were excluded, we could not entirely exclude conductive hearing loss because the KNHANES V did not include bone conduction audiometry. Second, we did not determine the factors or underlying conditions affecting the tendency for underestimation or overestimation, including tinnitus or history of exposure to noise. These variables can affect the manner in which individuals perceive their hearing status based on their age.

Large-scale studies have investigated the discrepancy between audiometric threshold and self-reported hearing level. Our study was also a large-scale study that included participants aged 40-79 years from the KNHANES V, who were likely to have physiological (or age-related) hearing loss. We identified the level of correlation between audiometric hearing level and self-reported hearing level with respect to age and determined the patterns of self-evaluation of hearing according to age. Moreover, we ascertained the cut-off values for the audiometric threshold for each age group at which individuals would perceive their hearing level as abnormal. Therefore, our study results can be useful for devising separate diagnostic criteria for pure tone audiometry-defined hearing loss for different age groups, which can be used to determine the need for hearing aid in a timely manner.

\section{Acknowledgments}

None.

\section{Author Contribution}

Conceptualization: Sung-Won Chae. Data curation: Seok-Youl Choi, Jee Won Moon. Formal analysis: Seok-Youl Choi, Jae-Jun Song, Sung-Won Chae. Investigation: Seok-Youl Choi, June Choi, Sung-Won Chae. Methodology: Seok-Youl Choi, Gi Jung Im. Project administration: Seok-Youl Choi, Sung-Won Chae. Supervision: Sung-Won Chae. Validation: Jae-Jun Song, Gi Jung Im. Writingoriginal draft: Seok-Youl Choi. Writing - review \& editing: SeokYoul Choi.

\section{ORCID}

Sung-Won Chae https://orcid.org/0000-0001-6401-352X

\section{REFERENCES}

1) Kim SY, Kim HJ, Kim MS, Park B, Kim JH, Choi HG. Discrepancy between self-assessed hearing status and measured audiometric evaluation. PLoS One 2017;12(8):e0182718.

2) Tremblay KL, Pinto A, Fischer ME, Klein BE, Klein R, Levy S, et al. Self-reported hearing difficulties among adults with normal audiograms: The Beaver Dam Offspring Study. Ear Hear 2015; 36(6):e290-9.

3) Kamil RJ, Genther DJ, Lin FR. Factors associated with the accuracy of subjective assessments of hearing impairment. Ear Hear 2015;36(1):164-7.

4) Choi JE, Moon IJ, Baek SY, Kim SW, Cho YS. Discrepancies between self-reported hearing difficulty and hearing loss diagnosed by audiometry: Prevalence and associated factors in a national survey. BMJ Open 2019;9(4):e022440.

5) Kiely KM, Gopinath B, Mitchell P, Browning CJ, Anstey KJ. Evaluating a dichotomized measure of self-reported hearing loss against gold standard audiometry: Prevalence estimates and age bias in a pooled national data set. J Aging Health 2012;24(3):43958.

6) Safari S, Baratloo A, Elfil M, Negida A. Evidence based emergency medicine; part 5 receiver operating curve and area under the curve. Emerg (Tehran) 2016;4(2):111-3.

7) Olusanya BO, Davis AC, Hoffman HJ. Hearing loss grades and the international classification of functioning, disability and health. Bull World Health Organ 2019;97(10):725-8.

8) Nondahl DM, Cruickshanks KJ, Wiley TL, Tweed TS, Klein R, Klein BE. Accuracy of self-reported hearing loss. Audiology 1998; 37(5):295-301.

9) Swanepoel de W, Eikelboom RH, Hunter ML, Friedland PL, Atlas MD. Self-reported hearing loss in baby boomers from the Busselton Healthy Ageing Study: Audiometric correspondence and predictive value. J Am Acad Audiol 2013;24(6):514-21; quiz 529.

10) Salonen J, Johansson R, Karjalainen S, Vahlberg T, Isoaho R. Relationship between self-reported hearing and measured hearing impairment in an elderly population in Finland. Int J Audiol 2011; 50(5):297-302. 


\section{정답 및 해설}

답 (4)

해 설 Castleman's disease

(1) Giant lymph node hyperplasia, 혈관여포성 림프절 과증식증(angiofollicular lymphoid hyperplasia)

양성 림프종(benign lymphoid hyperplasia), lymphoproliferative disorder의 특징을 가지며, cancer는 아니다.

(2) 원인 불명이며, 20-30대에 호발하나 성별에 따른 차이는 없다. 주로 동양인, 흑인보다 백인에 더 잘 발생하는 것으로 알 려져 있다.

(3) 다발성의 경우 systemic symptom이 동반되며, 사망률이 $10 \%-15 \%$ 이며, lymphoma 등의 악성병변으로 발달되는 경향이 있다. Human immunodeficiency virus (HIV), human herpesvirus 8 (HHV8), Kaposi sarcoma associated herpesvirus (KSHV)와 연관된 것으로 알려져 있다.

(4) 유리질혈관형이 더 흔한 형태이며, 단발성에 더 흔한 조직학적 소견이다. 형질세포형은 증상을 동반하며, 다발성에서 관찰 된다. 조직학적 소견상 hyalinized germinal centers with penetrating vessels, mantle zone (onion skinning)이 관찰된다. (5) 단발성은 수술적 완전절제가 원칙이며, 재발없이 완치가 가능하나 다발성은 아직 정립된 치료가 없으며, 치료에 반응이 좋지 않다. 수술, 스테로이드, 세포 독성화학요법, 방사선치료 등을 고려할 수 있다. 